\title{
Effect of Leadership Style of the Head of the Community Health Center and Other Determinants on the Health Personnel Performance in Boyolali, Central Java
}

\author{
David Marwandi1,2), Endang Sutisna Sulaeman²), Pawito3) \\ 1)Kapuas Hulu Health Office, West Kalimantan \\ 2)Masters Program in Public Health, Universitas Sebelas Maret \\ 3)Faculty of Social and Political Science, Universitas Sebelas Maret
}

\section{ABSTRACT}

Background: Leadership in health services is needed to utilize resources efficiently, design management processes, and encourage health workers to work towards achieving common goals. The purpose of this study was to analyze the effect of leadership style of the head of community health center and other determinants on the performance of health personnel.

Subjects and Method: This was an analytic observational study with a cross sectional design. The study was conducted in Boyolali, Central Java, from June to July 2019. A sample of 206 health personnel from 22 community health centers was selected for this study. The dependent variable was the performance of health personnel. The independent variables were perceived transformational leadership, perceived income, type of community health center, accreditation status, education level, tenure, training, community health center, and employee status. The data were collected by questionnaire and analyzed by a multilevel multiple linear regression.

Results: Health personnel performance increased with transformational leadership style $(b=$ 2.23; $95 \% \mathrm{CI}=0.94$ to 3.52 ; $\mathrm{p}<0.001)$, type of health workers $(b=1.80 ; 95 \% \mathrm{CI}=0.10$ to 3.49 ; $\mathrm{p}=0.037)$, and accreditation status $(\mathrm{b}=3.01 ; 95 \%$ $\mathrm{CI}=0.58$ to $5.44 ; \mathrm{p}=0.015)$. Health personnel performance increased with education $\geq$ Diploma
III $(b=0.55 ; 95 \% \mathrm{CI}=-1.46$ to $2.56 ; \mathrm{p}=0.592)$, tenure $\geq 3$ years $(\mathrm{b}=0.05 ; 95 \% \mathrm{CI}=-1.49$ to 1.59 ; $\mathrm{p}=0.947)$, adequate income $(\mathrm{b}=1.16 ; 95 \% \mathrm{CI}=-$ 0.10 to $2.42 ; \mathrm{p}=0.072$ ), and had attended training $(\mathrm{b}=0.67 ; 95 \% \mathrm{CI}=-0.68$ to $2.03 ; \mathrm{p}=0.329)$, but they were statistically non-significant. Health personnel performance decreased with the status of civil servant $(b=-1.32 ; 95 \% \mathrm{CI}=-3.82$ to 1.16 ; $\mathrm{p}=0.298$ ) and treatment status of community health center with hospitalization $(b=-2.97 ; 95 \%$ $\mathrm{CI}=-5.03$ to $-0.91 ; \mathrm{p}=0.005$ ).

Conclusion: Health personnel performance increases with transformational leadership style, type of health workers, accreditation status, education $\geq$ Diploma III, tenure $\geq 3$ years, adequate income, and had attended training. Health personnel performance decreases with the status of civil servant and treatment status of community health center with hospitalization.

Keywords: transformational leadership style, health personnel, performance.

\section{Correspondence:}

David Marwandi. Masters Program in Public Health, Universitas Sebelas Maret, Jl. Ir. Sutami 36A, Surakarta 57126, Central Java. Email: david.marwandi88@gmail.com. Mobile: +6281348789393 .

\section{Cite this as:}

Marwandi D, Sulaeman ES, Pawito (2020). Effect of Leadership Style of the Head of the Community Health Center and Other Determinants on the Health Personnel Performance in Boyolali, Central Java. J Health Policy Manage. 5(1): 74-84. https://doi.org/10.26911/thejhpm.2020.05.01.07

Journal of Health Policy and Management is licensed under a Creative Commons Attribution-Non Commercial-Share Alike 4.o International License. 


\section{BACKGROUND}

The world community has sufficient financial and technological resources to overcome most health challenges. What is needed now is to collaborate with international cooperation to align resources, utilize knowledge and build strong health systems to treat and prevent disease and improve population health. In developing the ability of health personnel, motivation is very important to support health personnel in overcoming obstacles to achieve national and global health goals (WHO, 2006).

Health personnel are very important for handling health problems in low and middle income countries, however, inadequate performance of health personnel is a very broad problem (Rowe et al., 2005). Performance of health personnel is a critical problem faced by many low and middle income countries (Jayasuriya et al., 2014)

To achieve an organization's goals and expected performance, it requires leadership, equipment resources, people, technology and control methods. WHO stated that the importance of leadership is increasingly emphasized in bringing about changes to improve health and welfare, especially by switching to SDGs. There is now a need and opportunity to act to strengthen leadership for health (WHO, 2016).

The health work system in Indonesia places community health center as the spearhead of health services. The meaning of the community health center itself refers to Minister of Health Regulations no 75 of 2014 which stated that there is a health service facility that organizes public health efforts and first-level individual health efforts. It emphasizes more on promoting efforts and prevention to achieve the highest degree of public health in its working area (RI Ministry of Health, 2014).

Health Profile of Central Java Province in 2017 where the data used was sourced from the results of the National SocioEconomic Survey (Susenas). The health service facilities obtained the number or percentage of the population who went for outpatient treatment at the community health center/supporting community health center was $25.6 \%$ smaller than the percentage of the population seeking medical treatment doctor or midwife by $52.9 \%$ (Statistics, 2017). In Boyolali, it was found that the most common way to get outpatient treatment was by goingto the practice of health personnel/ doctors/ midwives in the amount of 70.3\%. There were only $12.1 \%$ who went to the community health center / supporting community health center (Statistics, 2018)

On the basis of the problems above the researcher considers it necessary to conduct a study on the effect of the leadership style of the head of community health center and other determinants on the performance of health personnel in Boyolali, Central Java Province.

\section{SUBJECTS AND METHOD}

\section{Study Design}

The design of the study used in this study was an observational analytic study with a cross sectional approach. The study was conducted at 22 health centers in Boyolali, Central Java, Indonesia. This study was conducted JuneJuly 2019.

\section{Population and Sample}

The study population was health personnel in community health center. A sample of 206 health personnel from 22 community health centers was selected by stratified random sampling.

\section{Study Variables}

The dependent variable was the performance of health personnel. The independent variables were the perceived transformational leadership, perceived income, type of health center, accreditation status, level of educa- 
tion, length of work, training, health center treatment status, and employee status.

4. Operational Definition of Variables Performance was the behavior or action and all the results that contributed as expected or were the goal of the health center. There were three main branches of performance construction, namely task performance, contextual performance and adaptive performance. The data were collected by questionnaire. The measurement scale was continuous and transformed into dichotomous.

Perceived transformational leadership was the process of health personnel interpreting the sensational impression of the head of community health center in the way of leading. The data were collected by questionnaire. The measurement scale was continuous and transformed into dichotomous.

Type of health personnel of community health center was the health personnel consisting of health workers (doctors, nurses, midwives, etc.) and non-health workers (administrative personnel). The data were collected by questionnaire. The measurement scale was categorical.

Accreditation status of community health center was the level of accreditation at health center that is still valid at the time of data collection. The data were collected by questionnaire. The measurement scale was categorical.

Education was the official education level of respondents as health personnel. The data were collected by questionnaire. The measurement scale was categorical.

Tenure was the length of service of a health personnel at community health center. The data were collected by questionnaire. The measurement scale was continuous and transformed into dichotomous.

Perceived income was what is felt by the health personnel on the amount of income earned during a month. The data were collected by questionnaire. The measurement scale was continuous and transformed into dichotomous.

Training was the status of health personnel who had or never received training while working at the community health center. The data were collected by questionnaire. The measurement scale was categorical.

Employee status was the status of the respondent as a civil servant / temporary employee, honorarium/internship. The data were collected by questionnaire. The measurement scale was categorical.

Treatment status of community health center was the status of a community health center as an inpatient community health center or non-inpatient community health center. The data were collected by questionnaire. The measurement scale was categorical.

\section{Data Analysis}

Univariate analysis was explained in the sample characteristics described in $\mathrm{n}$, mean, $\mathrm{SD}$, min and max, categorical data described in $\mathrm{n}$ and percent (\%). Bivariate analysis used chi square test to determine corelation between the performance of health personnel and the independent variables. Multivariate analysis used multilevel linear regression analysis used the Stata 13 program.

\section{Research Ethic}

Research ethics includes consent sheets, anonymity, confidentiality, and ethical eligibility. The ethical feasibility of this study came from the Health Research Ethics Committee of Dr. Regional General Hospital. Moewardi Surakarta with number: 723 / V / HREC / 2019.

\section{RESULTS}

1. Sample Characteristics

Sample characteristics of continuous data were described in Table 1 . Sample characteristics of categorical data were described in Table 2.

\section{Bivariate Analysis}

The results of the bivariate analysis showed perceived transformational leadership $(\mathrm{OR}=$ 
Marwandi et al./Effect of Leadership Style of the Head of the Community Health Center

3.17; $\mathrm{p}=<0.001)$ accreditation $\geq$ intermediate $(\mathrm{OR}=2.36 ; \mathrm{p}=0.011)$, adequate income $(\mathrm{OR}=1.93 ; \mathrm{p}=0.021)$, had attended training $(\mathrm{OR}=2.52 ; \mathrm{p}=0.003)$, had an effect on improving the performance of personnel health and was statistically significant. Education $\geq D_{3}(\mathrm{OR}=1.20 ; \mathrm{p}=0.667)$, employees status civil servant/ temporary employee (OR= $0.43 ; \mathrm{p}=0.156)$, type of health personnel status $(\mathrm{OR}=1.16 ; \mathrm{p}=0.659)$, tenure $\geq 3$ years $(\mathrm{OR}=0.99 ; \mathrm{p}=0.999)$, increased health personnel performance. Inpatient status $(\mathrm{OR}=$ $0.55 ; \mathrm{p}=0.043$ ) decreased health personnel performance.

Table 1. Sample characteristics of continuous data

\begin{tabular}{lccccc}
\hline Variables & n & Mean & SD & Min. & Max. \\
\hline Education & 206 & 2.08 & 0.62 & 0 & 3 \\
Accreditation & 206 & 1.86 & 0.54 & 1 & 3 \\
Treatment status & 206 & 0.59 & 0.49 & 0 & 1 \\
Employee status & 206 & 3.8 & 0.58 & 1 & 4 \\
Type of health personnel & 206 & 0.79 & 0.40 & 0 & 1 \\
Tenure & 206 & 3.11 & 1.22 & 1 & 4 \\
Perceived income & 206 & 4.13 & 1.12 & 1 & 5 \\
Training & 206 & 0.68 & 0.46 & 0 & 1 \\
Perceived transformational leadership & 206 & 24.7 & 4.75 & 9 & 32 \\
Performance & 206 & 51.66 & 5.34 & 36 & 64 \\
\hline
\end{tabular}

Table 2. Sample characteristics of categorical data

\begin{tabular}{|c|c|c|}
\hline Variables & Frequency & Percentage (\%) \\
\hline \multicolumn{3}{|l|}{ Education } \\
\hline$\geq$ Diploma III & 180 & 87.38 \\
\hline$<$ Diploma III & 26 & 12.62 \\
\hline \multicolumn{3}{|l|}{ Accreditation } \\
\hline$\geq$ Intermediate & 160 & 77.67 \\
\hline$<$ Basic & 46 & 22.33 \\
\hline \multicolumn{3}{|l|}{ Treatment status } \\
\hline Inpatient & 123 & 50.71 \\
\hline Non-inpatient & 83 & 40.29 \\
\hline \multicolumn{3}{|l|}{ Employee status } \\
\hline Civil servant/Temporary employees & 190 & 92.23 \\
\hline Honorarium/Internship & 16 & 7.77 \\
\hline \multicolumn{3}{|l|}{ Type of health workers } \\
\hline Health workers & 164 & 79.61 \\
\hline Non-health workers & 42 & 20.39 \\
\hline \multicolumn{3}{|l|}{ Tenure } \\
\hline$\geq 3$ years & 161 & 78.16 \\
\hline$<3$ years & 45 & 21.48 \\
\hline \multicolumn{3}{|l|}{ Perceived Income } \\
\hline Adequate & 114 & $55 \cdot 34$ \\
\hline Inadequate & 92 & 44.66 \\
\hline \multicolumn{3}{|l|}{ Training } \\
\hline Attended training & 142 & 68.93 \\
\hline Never attended training & 64 & 31.07 \\
\hline \multicolumn{3}{|c|}{ Perceived transformational leadership } \\
\hline Transformative & 133 & 64.56 \\
\hline Non-transformative & 73 & 35.44 \\
\hline \multicolumn{3}{|l|}{ Performance } \\
\hline Good & 119 & 57.77 \\
\hline Poor & 87 & 42.23 \\
\hline
\end{tabular}


Marwandi et al./Effect of Leadership Style of the Head of the Community Health Center

Table 3. The Results of Bivariate Analysis

\begin{tabular}{|c|c|c|c|c|c|c|c|c|}
\hline \multirow{3}{*}{$\begin{array}{c}\text { Independent } \\
\text { Variables }\end{array}$} & \multicolumn{4}{|c|}{ Performance assessment } & \multirow{2}{*}{\multicolumn{2}{|c|}{ Total }} & \multirow{3}{*}{ OR } & \multirow{3}{*}{$\mathbf{p}$} \\
\hline & \multicolumn{2}{|c|}{ Poor } & \multicolumn{2}{|c|}{ Good } & & & & \\
\hline & $\mathbf{N}$ & $\%$ & $\mathbf{N}$ & $\%$ & $\mathbf{N}$ & $\%$ & & \\
\hline \multicolumn{9}{|l|}{ Education } \\
\hline$\geq$ Diploma III & 75 & 36.4 & 105 & 51 & 180 & $87 \cdot 3$ & 1.20 & 0.667 \\
\hline$<$ Diploma III & 12 & 5.8 & 14 & 6.7 & 26 & 12.7 & & \\
\hline \multicolumn{9}{|l|}{ Accreditation } \\
\hline$\geq$ Intermediate & 60 & 29.13 & 100 & 77.67 & 160 & 77.67 & 2.36 & 0.011 \\
\hline$<$ Basic & 27 & 13.11 & 19 & 9.22 & 46 & 22.33 & & \\
\hline \multicolumn{9}{|l|}{ Treatment Status } \\
\hline Inpatient & 59 & 28.65 & 64 & 31.07 & 123 & $59 \cdot 71$ & 0.55 & 0.043 \\
\hline Non-inpatient & 28 & 13.59 & 55 & 26.70 & 83 & 40.29 & & \\
\hline \multicolumn{9}{|l|}{ Employee Status } \\
\hline Civil servant & 83 & 40.29 & 107 & 51.94 & 190 & 92.23 & 0.43 & 0.156 \\
\hline Honorarium/Internship & 4 & 1.94 & 12 & 5.83 & 16 & 7.77 & & \\
\hline \multicolumn{9}{|l|}{ Type of health personnel } \\
\hline Health personnel & 68 & 33.01 & 96 & 46.60 & 164 & 79.61 & 1.16 & 0.659 \\
\hline Non-health personnel & 19 & 9.22 & 23 & 11.17 & 42 & 20.39 & & \\
\hline \multicolumn{9}{|l|}{ Work Length } \\
\hline$\geq 3$ years & 68 & 33.01 & 93 & 45.15 & 161 & 78.16 & 0.99 & 0.999 \\
\hline$<3$ years & 19 & 9.22 & 26 & 12.62 & 45 & 21.84 & & \\
\hline \multicolumn{9}{|l|}{ Perceived income } \\
\hline Adequate & 40 & 19.42 & 74 & 35.92 & 114 & $55 \cdot 34$ & 1.93 & 0.021 \\
\hline Inadequate & 47 & 22.82 & 45 & 21.48 & 92 & 44.66 & & \\
\hline \multicolumn{9}{|l|}{ Training } \\
\hline Had attended training & 50 & 24.27 & 92 & 44.66 & 142 & 68.93 & 2.52 & 0.003 \\
\hline Had never attended training & 37 & 17.96 & 27 & 13.11 & 64 & 31.07 & & \\
\hline \multicolumn{9}{|l|}{$\begin{array}{l}\text { Perceived } \\
\text { transformational } \\
\text { leadership }\end{array}$} \\
\hline Transformative & 43 & 20.87 & 90 & 43.69 & 133 & 64.56 & 3.17 & $<0.001$ \\
\hline Non-transformative & 44 & 21.36 & 29 & 14.08 & 73 & 35.44 & & \\
\hline
\end{tabular}

\section{Multilevel Analysis}

The method used was multilevel multiple linear regression with the help of Stata 13. The results of the multivariate analysis in table 3 show the transformational leadership style $(b=2.23 ; 95 \% \mathrm{CI}=0.94$ to $3.52 ; \mathrm{p}$ $<0.001)$, type of personnel health $(\mathrm{b}=1.80$; $95 \% \mathrm{CI}=0.10$ to $3.49 ; \mathrm{p}=0.037)$, accreditation status $\geq$ intermediate $(\mathrm{b}=3.01 ; 95 \% \mathrm{CI}=$ 0.58 to $5.44 ; \mathrm{p}=0.015$ ) increased health personnel performance and it was statistically significant. Education $\geq$ Diploma III $(\mathrm{b}=0.55$; 95\% $\mathrm{CI}=-1.46$ to $2.56 ; \mathrm{p}=0.592$ ), tenure $\geq 3$ years $(\mathrm{b}=0.05 ; 95 \% \mathrm{CI}=-1.49$ to $1.59 ; \mathrm{p}=$ $0.947)$, adequate perceived income $(b=1.16$; 95\% CI $=-0.10$ to $2.42 ; \mathrm{p}=0.072$ ), had attended training $(\mathrm{b}=0.67 ; 95 \% \mathrm{CI}=-0.68$ to
2.03; $\mathrm{p}=0.329$ ) increased health personnel performance, but it was statistically non-significant. Status of employees civil servant $(\mathrm{b}=$ -1.32 ; $95 \% \mathrm{CI}=-3.82$ to $1.16 ; \mathrm{p}=0.298) \mathrm{de}-$ creased health personnel performance, but it was statistically non-significant. Inpatient community health center $(\mathrm{b}=-2.97 ; 95 \% \mathrm{CI}=$ -5.03 to $-0.91 ; \mathrm{p}=0.005$ ) decreased health personnel performance and it was statistically significant. There was a contextual effect of community health center on health personnel performance with $\mathrm{ICC}=19.8 \%$. It means that $19.8 \%$ of the variation in the performance of health personnel was determined by variables at the community health center level. 
Marwandi et al./Effect of Leadership Style of the Head of the Community Health Center

Table 4. The results of multilevel multiple linear regression analysis

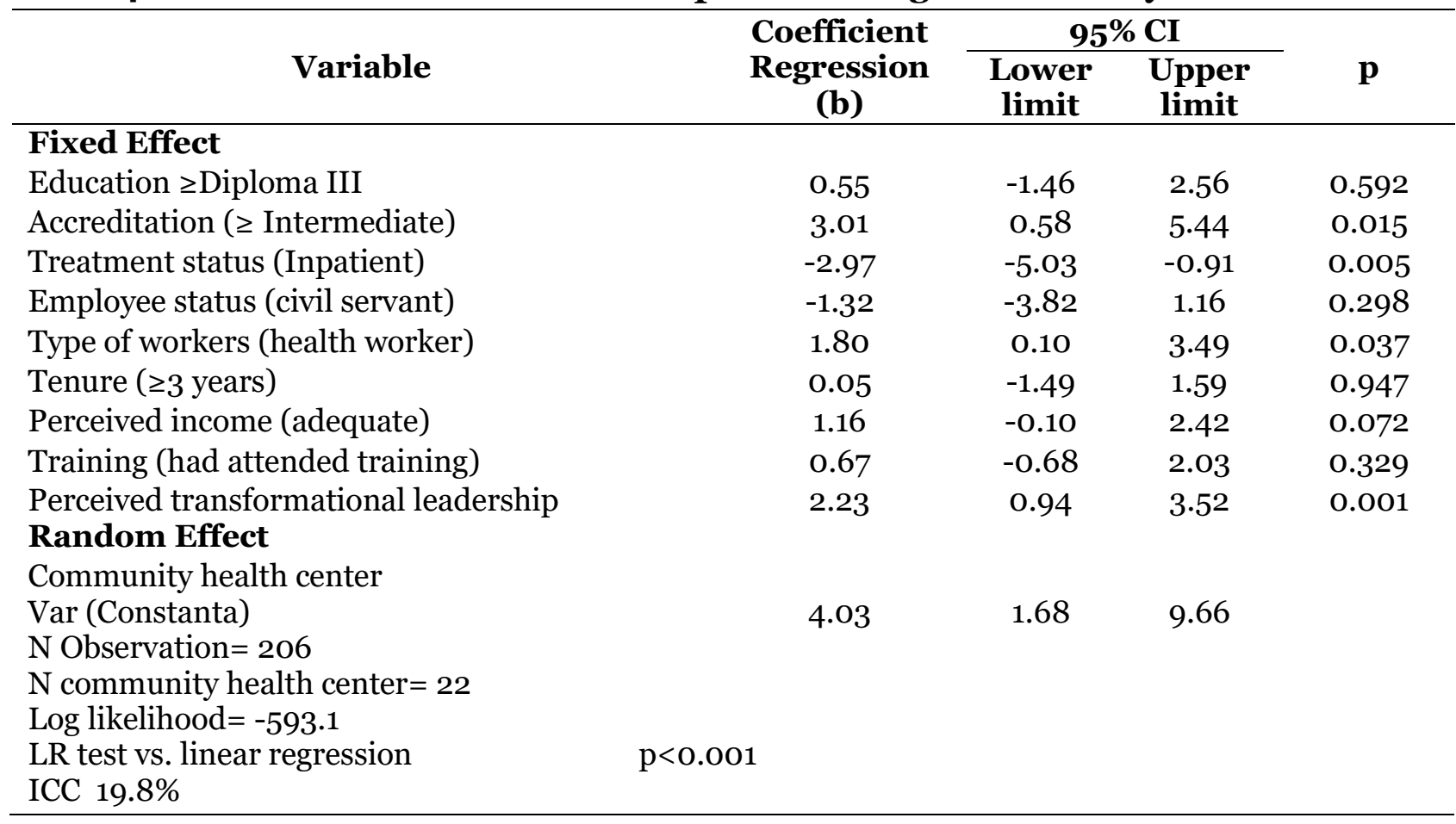

DISCUSSION

1. The effect of education on the performance of health personnel

There was a positive effect on the level of education on the performance of health personnel but was not significant. Third level of associate's degree education level or more increases the performance of health personnel with a logodd of 0.55 units than at the education level less than third level of associate's degree.

The results of the same study found that the level of education had a positive but not significant effect on the performance of North Sulawesi Provincial Health Office employees. The level of education of employees does not guarantee more optimal employment or employees with higher levels of education do not necessarily have good performance because there are still many levels of education that are not in accordance with their fields of work (Onibalaet al., 2017).

According to Gusnetti (2014), education is part of human investment. The longer time a person takes for education and the higher the ability or competence to do work, the better the performance.

\section{The effect of accreditation on the performance of health personnel}

There was a positive effect on the status of accreditation of community health center on the performance of health personnel. The accreditation status of community health center $\geq$ Intermediate improves the performance of health personnel with logodd of 3.01 units compared to < Intermediate accreditation status.

This is in line with Ensha (2018), which stated that the Implementation of Community Health Center Accreditation Policy has a significant effect on Employee Work Productivity. While the direct effect of Community Health Center Accreditation Policy Implementation on Employee Work Productivity is $7.04 \%$.

A study conducted on the impact of accreditation on primary health care organizations in the Middle East stated that on the main health care organizations in the State of Qatar also gain the same result where 
all employees of the main health care organizations in the State of Qatar agreed to the positive impact of accreditation. The results also showed a significant positive correlation between health personnel perceived accreditation and quality of care (Ghareebet al., 2018). Accreditation is an external assessment strategy to measure the quality of health services (Sulistyo et al., 2018).

\section{The effect of health center care status on the performance of health personnel}

There was a negative effect on the inpatient status of community health center on the performance of health personnel. The inpatient status of community health center reduced the performance of health personnel with logodd of -2.97 units compared to the status of community health center with noninpatient.

The results of the study of Performance the community health center measurement based on the community satisfaction index aim to see the extent of the performance of Inpatient and Outpatient Community Health Center in North Minahasa Regency conducted by Rotty (2016) obtained a significant level of 0.159 (above $5 \%$ or above 0.05). This shows that there is no significant difference in the performance of health services at the Inpatient and Outpatient Health Centers in North Minahasa. Health services at inpatient and outpatient community health center tend to provide the same service because consumer satisfaction is relatively the same in both types of community health center.

Decreased performance of inpatient health personnel can be caused by many factors one of which is fatigue resulting in increased work intensity / increasingly busy, lack of attention and less effective communication between employees or to leaders and can also be caused by lack of number of employees.

\section{The effect of employee status on the performance of health personnel}

There was a negative but not significant effect on the employee status of civil servant on the performance of health personnel. The employee status of civil servant/ temporary employee of community health center reduces the performance of health personnel with logodd of -1.32 units compared to the employee's status of non-civil servant /temporary employee.

A study by Saefulloh (2013) stated that nurses in the inpatient room of Indramayu Hospital got no different results where civil servant nurses had an average performance of 85.54 and non-civil servant nurses had an average performance of 84.32 . The difference in performance between civil servant nurses and non-civil servant nurses was 1.22 points. The results of the statistical test showed $\mathrm{p}=$ 0.520 ( $\alpha$ 0.05) meaning that there were no significant differences between the performance of civil servant nurses and non-civil servant nurses in the inpatient room of Indramayu Hospital. This can be due to nurses who are non-civil servants have the same responsibility in providing nursing care to patients.

\section{The effect of type of human resour- ces on the health personnel perfor- mance}

There was a positive effect on the type of human resources on the performance of health personnel. The type of HR for health workers increased the performance of health personnel by logodd of 1.80 units rather than the type of HR for non-health workers $(b=1.80$; 95\% CI= 0.10 to $3.49 ; \mathrm{p}=0.037$ ).

Various studies show that health workers are the main key in the successful achievement of health development goals. Health workers contribute up to $80 \%$ in the success of health development (MOH RI, 2014) 


\section{Effect of tenure on the health per- sonnel performance}

There was a positive effect on length of service on the performance of health personnel but was not significant. The length of work of health personnel $\geq 3$ years increases the performance of health personnel with logodd of 0.05 units compared to the length of service of employees $<3$ years.

A study by Gusti et al. (2018) suggests that there is a correlation between work length and midwife performance. Midwives who work $\geq 3$ years increase the likelihood of good performance $((\mathrm{b}=1.57 ; 95 \% \mathrm{CI}=0.11$ to 3.02; $\mathrm{p}=0.035$ ).

This is in line with the results of a study conducted by Rahmadaniet al. (2019) which stated that that there is a significant effect of work length on midwife performance. Midwives who have $\geq 13$ years of work are more likely to have good performance 1.89 times higher than midwives who have $<13$ years of work $(b=1.89 ; 95 \% \mathrm{CI}=-0.07$ to $3.86 ; \mathrm{p}=$ 0.059 ).

A study by Olatunji and Mokuolu (2014), also shows that performance increases with the increase in work length. Health workers who have $>10$ years of work are more satisfied with their performance compared to health workers who have $<10$ years of work. Work experience can reduce stress levels which then increase satisfaction and performance. New health workers $(<10$ years) have concerns, fatigue, frustration, and job dissatisfaction which ultimately affect their performance.

\section{The effect of perceived income on the health personnel performance}

There was a positive effect of perceived income on the performance of health personnel. Adequate perceived income improve the performance of health personnel with logodd of 1.16 units rather than perceived income.

This is in line with a study by Posuma (2013) at the RS. Ratumbuy-sang Manado which stated that hypothesis and regression test results showed that the resulting significant value of $<0.001$ with $\mathrm{p}=0.05$. It means that Compensation has a significant effect on health personnel of Ratumbuysang Manado hospital. It can also be interpreted as the better the compensation given to employees, the more enthusiastic they will be in doing work and producing good performance too.

Sulaeman study (2014) reported a significant effect between the wage level on the work productivity. A positive relationship between wage and employee productivity was also revealed by Leibenstein in Priadana (2010) which explained that labor productivity has a positive correlation with the level of wages paid by companies. So he suggested in developing countries that relatively higher wage levels would improve health and nutritional standards, which in turn would indirectly increase labor productivity.

\section{The effect of training on the health personnel performance}

There was a positive effect of training on the performance of health personnel but it is not significant. Health personnel who have attended training improve the performance of health personnel with logodd of 0.67 units compared to health personnel who have never attended training.

Alhudhori's study (2018) stated the same positive effect but in this study the results of the training variable have a very significant effect on the performance.

A study by Handayani and Ma'ruf (2012) on "The role of health workers as implementers of health services in puskesmas" found that as many as $78.6 \%$ of health workers think that improving education and skills through training will improve their performance individually in the role of executors health service at the community health center.

Training is an activity that is programmed to increase expertise, experience and 
knowledge. The expected output from training is the creation of trained human resources so as to be able to do short-term operational tasks better. Health personnel who do not attend training will study longer in carrying out operational tasks that they have never received. Similarly, employees who do not attend training will be relatively more difficult to complete operational tasks more effectively because there is no update on the technical ability to complete the work (Masukuet a, 2019).

\section{The effect of transformational lea- dership style on the performance of health personnel}

There was a positive effect on transformational leadership style on the performance of health personnel. Transformational leadership style increases the performance of health center employees with a logodd of 2.23 units rather than a non-transformational leadership style.

This is in line with a study conducted Nur's (2017) that transformational leadership had a significant effect on health personnel $(b=0.29 ; p<0.001)$. It indicates that transformational leadership can improve employee performance.

Miao and Cao (2019), who use a sample of large and medium-sized companies in China, stated that when employees perceive a higher level of transformational leadership, a positive correlation between work welfare and employee creativity is stronger. So that work welfare will have more effect on the work performance system high on employee creativity.

In general, transformational leadership positively predicts positive welfare measures (Arnold, 2017). Transformational leadership also reduces employees' work stress in the hospitality service industry. It can be said that employees who are more committed to their organization's mission, goals and objectives (transformational leadership out- comes), will feel less work pressure than those who are less committed (Gillet al., 2010).

\section{The contextual effect of community health center on the performance of health personnel}

The results of the analysis show that there was a random effect of community health center contextual factors on the variation of multiple linear regression constants. LR test vs. Linear Regression shows the value of $\mathrm{p}<0.001$ which means there is a statistically significant difference between the multilevel linear regression analysis model and the usual linear regression model. $\mathrm{ICC}=19.8 \%$ means that $19.8 \%$ of the variation in the performance of health personnel is determined at the contextual level of community health center.

\section{AUTHOR CONTRIBUTION}

David Marwandi was the main researcher. He implemented the study, collected the data, formulated articles of the study and processed data. Endang Sutisna Sulaeman formulate of a framework of the study. Pawito formulate of methods of the study and discussion of the results.

\section{CONFLICT OF INTEREST}

There is no conflict of interest in this study.

FUNDING AND SPONSORSHIP

The source of funds in this study used grants from the Central Agency for the Improvement of Health Human Resources Quality (BPPSDMK) Ministry of Health of the Republic of Indonesia.

\section{ACKNOWLEDGEMENT}

The researchers would like to thank the Health Office and Boyolali Health Center for allowing this study to be carried out. Thank you to all respondents who had been willing and cooperative to become subjects of the study. 
Marwandi et al./Effect of Leadership Style of the Head of the Community Health Center

\section{REFERENCE}

Alhudhori M (2018). Pengaruh pelatihan terhadap kinerja pegawai pada Puskesmas Simpang Kawat Kota Jambi. J. Ilm. Univ. Batanghari Jambi, 18(3): 654. https://doi.org/10.33087/jiubj.v18i3.533 .

Arnold KA (2017). Transformational leadership and employee psychological wellbeing: a review and directions for future research. J Occup Health Psychol, 2(30). https://doi.org/10.1037/ocpoo00062

BPS (2017). Profil kesehatan Provinsi Jawa Tengah 2017. Semarang. Retrieved from https://jateng.bps.go.id

BPS (2018). Statistik Daerah Kabupaten Boyolali 2018. Retrieved from https://boyolalikab.bps.go.id

Ensha IS (2018). Pengaruh implementasi kebijakan akreditasi puskesmas terhadap manajemen pelayanan kesehatan masyarakat dalam mewujudkan produktivitas kerja. Jurnal Publik: Jurnal Ilmiah Bidang Ilmu Administrasi Negara, 12(01): 12-23. Retrieved from http://journal.uniga.ac.id/index.php/JPB/article/view/283

Ghareeb A, Said H, El Zoghbi M (2018). Examining the impact of accreditation on a primary healthcare organization in Qatar. BMC Med. Educ, 18(1): 1-8. https://doi.org/10.1186/-s12909-0181321-O

Gill A, Flaschner AB, Bhutani S (2010). The impact of transformational leadership and empowerment on employee job stress. J. Bus. Econ, 1(1). https://doi.org/10.4172/2151-6219.1000003

Gusnetti (2014). Faktor-faktor yang mempengaruhi kinerja karyawan pada PT. Garuda Indonesia Pekanbaru. Journal FISIP Universitas Riau, 1(2): 1-11. https://jom.unri.ac.id/index.php/JOM
FSIP/index

Handayani L, Ma'ruf N (2012). Peran tenaga kesehatan sebagai pelaksana pelayanan kesehatan puskesmas.HSR, 13. https://doi.org/10.22435/bpsk.v13i1Jan.2752

Jayasuriya R, Jayasinghe UW, Wang Q (2014). Health worker performance in rural health organizations in low- and middle-income countries: Do organizational factors predict non-task performance? Soc Sci Med, 113: 1-4. https://doi.org/10.1016/j.socscimed.2014.0 4.042.

Kemenkes RI (2014). Rencana pengem-bangan tenaga kesehatan tahun 2011 2025. Kemenkes RI. Retrieved from www.who.int/workforcealliance/countr ies/inidonesia_hrhplan_2011_2025.pd $\mathrm{f}$

Masuku S, Lengkong VPK, Dotulong LOH (2019). Pengaruh pelatihan, budaya kerja dan gaya kepemimpinan terhadap produktivitas kerja karyawan pada Pt. Askrindo Cabang Manado. EMBA, 7(1), 821-830. https://ejournal.unsrat.ac.id/index.php/emba/article/view/22909

Miao R, Cao Y (2019). High-performance work system, work well-being, and employee creativity: Cross-level moderating role of transformational leadership. Int. J. Environ. Res. Public Health, 16(9): 1-24. https://doi.org/10.3390/ijerph-16091640

Ministry of Health (2014). Permenkes RI No 75 tahun 2014 tentang Pusat Kesehatan Masyarakat. Jakarta. Retrieved from http://www.kemkes.go.id

Nur MA (2017). Pengaruh kepemimpinan transformasional terhadap kekompakan, keterlibatan kerja dan kinerja pegawai (studi penyusunan dokumen perencanaan pembangunan satuan kerja perangkat daerah Kabupaten Kota- 
Marwandi et al./Effect of Leadership Style of the Head of the Community Health Center

baru). Jurnal Bisnis Dan Pembangunan, 6(1). https://ppjp.ulm.ac.id.

Olatunji SO, Mokuolu BO (2014). The influence of sex, marital status, and tenure of service on job stress, and job satisfaction of health workers in a nigerian federal health institution. Afr. Res. Rev, 8(32), 126-133.

Onibala R, Kojo C, Uhing Y (2017). Pengaruh tingkat pendidikan dan kompensasi terhadap kinerja pegawai pada dinas kesehatan Provinsi Sulawesi Utara. EMBA, 5(2), 1929-1934. Retrieved from https://ejournal.unsrat.ac.id

Posuma C (2013). Kompetensi, kompensasi dan kepemimpinan pengaruhnya terhadap kinerja karyawan pada Rumah Sakit Ratumbuysang Manado. EMBA, 1(4): 646-656. https://ejournal.unsrat.ac.id

Rahmadani LN, Budihastuti UR, Pamungkasari EP (2019). Does health center have contextual effect on midwife performance? Multilevel analysis evidence from East Kalimantan, Indonesia. J Health Policy Manage, 4, 150-160. https://doi.org/10.26911/the-jhpm.2019.04.03.01

Rotty S (2016). Komparasi kinerja layanan kesehatan pada puskesmas rawat inap dengan rawat jalan di Kabupaten Minahasa Utara. EMBA, 4(2): 311-322. Retrieved from https://ejournal.unsrat.ac.id

Rowe AK, De Savigny D, Lanata CF, Victora
CG (2005). How can we achieve and maintain high-quality performance of health workers in low-resource settings? Lancet, 366(9490), 1026-1035. https://doi.org/10.1016/So1406736(05)67028-6

Saefulloh M (2013). Pengaruh status kepegawaian terhadap kinerja perawat di ruang rawat inap.jurnal kebidanan dan keperawatan, 9(1); 65-73. Retrieved from http://digilib.unisayogya.ac.id.

Sulaeman A (2014). Pengaruh upah dan pengalaman kerja terhadap produktivitas karyawan kerajinan ukiran Kabupaten Subang. Trikonomika, 13(1): 91-10o.https://journal.unpas.ac.id

Sulistyo SA, Tamtomo D, Sulaeman ES (2018). Accreditation status and other factors affecting patient satisfaction in hospital. J Health Policy Manage, 139149. https://doi.org/10.26911/thejhpm.2019.04.03.01

Gusti TE, Tamtomo D, Murti B (2018). Determinants of midwife performance on antenatal care in Surakarta and Karanganyar, Central Java. J Health Policy Manage, 3(1), 26-33. https://-doi.org/10.26911/thejhpm.2018.03.01.04

WHO (2006). Working together for health. World Health Organization. https://doi.-org/10.1186/1471-2458-5-67

WHO (2016). Open mindset; participatory leadership for health. Geneva. https://www.who.int 